(๖) 2018 - ISSN 1807-2577

\title{
Association between normative and perceived esthetic results after treatment of mandibular retrognathism
}

\author{
Associação entre os resultados estéticos normativos e percebidos \\ pós-tratamento do retrognatismo mandibular
}

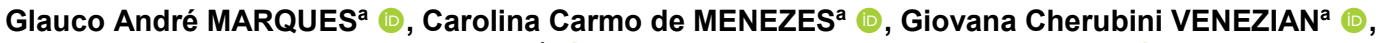
José Fernando Castanha HENRIQUES ${ }^{b}$ (i), Silvia Amélia Scudeler VEDOVELLO ${ }^{a}$ (D), Viviane Veroni DEGAN ${ }^{a^{*}}$ (1)

aUNIARARAS - Centro Universitário Hermínio Ometto, Departamento de Ortodontia, Araras, SP, Brasil

'USP - Universidade de São Paulo, Faculdade de Odontologia de Bauru, Departamento de Ortodontia, Bauru, SP, Brasil

How to cite: Marques GA, Menezes CC, Venezian GC, Henriques JFC, Vedovello SAS, Degan VV. Association between normative and perceived esthetic results after treatment of mandibular retrognathism. Rev Odontol UNESP. 2019;48:e20190066. https://doi.org/10.1590/1807-2577.06619

\begin{abstract}
Resumo
Introdução: Este estudo transversal buscou associar resultados cefalométricos normativos do tratamento do retrognatismo mandibular com melhora estética do perfil facial na percepção do paciente. Objetivo: este estudo transversal buscou associar resultados cefalométricos normativos do tratamento do retrognatismo mandibular com melhora estética do perfil facial na percepção do paciente. Material e método: Os resultados cefalométricos normativos obtidos em radiografias cefalométricas laterais de uma amostra de 24 pacientes com maloclusão de Classe II em fase de crescimento tratados com aparelho de avanço mandibular, foram avaliados comparando-se as grandezas pré e pós-tratamento. As mesmas radiografias foram utilizadas para gerar silhuetas negras padronizadas que foram dispostas aleatoriamente. Os pacientes foram instruídos a escolher seu perfil preferido e indicar quanta mudança foi percebida por meio de uma escala de Likert de 7 pontos. Os dados foram comparados com resultados cefalométricos aplicando-se metodologia de modelos mistos para medidas repetidas no tempo, teste $t$ de student e teste t para variâncias heterogêneas, com nível de significância de $5 \%$. Resultado: $75 \%$ dos pacientes escolheram silhuetas pós-tratamento e a mudança foi percebida independentemente da escolha por pré ou pós-tratamento. Não houve diferença significativa entre as variáveis cefalométricas dos traçados que deram origem às silhuetas consideradas melhores e piores após a avaliação. Conclusão: Não houve associação entre os resultados cefalométricos pós-tratamento e a percepção da melhora estética por pacientes ortodônticos.
\end{abstract}

Descritores: Estética; beleza; ortodontia; ortopedia.

\begin{abstract}
Introduction: This cross-sectional study aimed to associate the normative cephalometric results of mandibular retrognathism treatment with patient perception on the esthetic improvement of facial profile. Objective: this cross-sectional study aimed to associate the normative cephalometric results of mandibular retrognathism treatment with patient perception on the esthetic improvement of facial profile. Material and method: The normative cephalometric results were obtained from lateral cephalometric radiographs of a sample of 24 Class II malocclusion patients in the pubertal growth spurt. Such patients were treated with a mandibular advancement device and evaluated by comparing pre- and post-treatment variables. The same radiographs were used to produce standardized black silhouettes that were randomly arranged. Patients were instructed to choose their preferred profile and indicate the changes perceived using a 7-point Likert scale. The data were compared with cephalometric results using a mixed-model methodology for time-repeated measures, Student's t-test, and t-test for heterogeneous variances, at 5\% significance level. Result: A rate of $75 \%$ of patients preferred posttreatment silhouettes and changes were perceived regardless of the choice of either pre- or post-treatment profile. There was no significant difference between the cephalometric variables of the tracings that produced
\end{abstract}


the silhouettes considered better or worse after the evaluation. Conclusion: There was no association between the cephalometric results after treatment and the perception of esthetic improvement by patients treated for mandibular retrognathia.

Descriptors: Esthetics; beauty; orthodontics; orthopedics.

\section{INTRODUCTION}

Patients with more severe malocclusions suffer greater impacts on quality of life, which affect emotional aspects and social well-being ${ }^{1}$. Therefore, the dissatisfaction with dental appearance is a strong predictor of self-esteem ${ }^{2}$. The demand for orthodontic therapy is more related to the search for facial esthetics than to functional problems and is therefore essential for personal patient satisfaction with smile and facial esthetics at the end of treatment ${ }^{3}$. Orthodontists are challenged to determine the amount of dental repositioning with repercussions on soft tissues so that change is perceived as positive at the end of treatment.

The cephalometric analysis is a tool capable of predicting changes in soft and hard tissues and their influence on facial profile ${ }^{4}$. This is based typically on normative values used as reference. However, in some cases such as treatments with anterior mandibular projection, the correction of discrepancies results in dentoalveolar readaptation, which satisfactorily corrects the initial problem, but worsens the positioning of some structures if considering the normative reference 5 . Alternatively, the same devices that changed the standards also produced results approved in studies focusing on facial perception ${ }^{6,7}$.

This situation is reflected based on the verification that certain normative rules followed in orthodontic planning may be broken and yet lead to a feeling of improvement at the end of treatment. By the same reasoning, it would be necessary to evaluate whether this variation in normative measures would affect directly the ability to identify improvement so that the variation might be used as reference for treatment planning.

The literature has poorly described the investigation on the association between perception of esthetic results and cephalometric norms after treatment ${ }^{8,9}$. Similarly, most perception studies have used different evaluators such as laypeople, orthodontists, and dental students, and a few

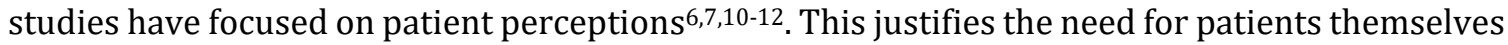
to evaluate esthetic perception, as they might provide useful information when seeking to associate these data with those of cephalometric standards.

According to the aforementioned, this study aimed to verify the association between normative cephalometric results and the perception of esthetic improvement by patients treated for mandibular retrognathia.

\section{MATERIAL AND METHOD}

The Ethics Committee of the institution selected approved this study (protocol \#58297716.8.0000.5385).

To determine the sample size, the calculation was preset at $5 \%$ of type 1 errors (Alpha), $80 \%$ test power, and mean difference of 0.8 degrees with standard deviation of 0.97 , using the SNB variable as reference. These parameters determined the need for a sample of 24 participants.

The inclusion criteria required volunteers treated orthodontically with the Herbst mandibular advancement device ${ }^{13}$, without tooth extractions, and in the pubertal growth spurt during therapy confirmed by the assessment of cervical vertebrae maturation ${ }^{14}$. They should also present Class II molar relationship (verified clinically and in plaster casts) before treatment, Class I relationship after treatment, initial ANB angle $\geq 4^{\circ}$ (showing Class II skeletal relationship), and SNB angle $\leq 80^{\circ}$ (identifying the tendency towards mandibular retrusion). 
According to the criteria described, 48 pre- and post-treatment digital lateral teleradiographs were selected from patients of both sexes (11 boys and 13 girls), with initial age between 9.5 and 14.2 years (mean of 11.6 years and standard deviation of 1.36) and between 10.1 and 16 years at the end of therapy (mean of 13 years and standard deviation of 1.48). The sample was considered homogeneous when analyzing the sex of the volunteers. The sample included $54.22 \%$ of male participants and $45.8 \%$ of female participants.

The digital cephalometric radiographs were submitted to cephalometric analysis with 21 variables, traced, and measured by a single operator using the Radiocef Studio 2 software (version 2.0, Radio Memory LTDA, Belo Horizonte, Brazil). Method error was applied comparing all variables retraced 30 days after the first evaluation. The intra-examiner error showed no statistically significant differences ( $p>0.05)$.

The same cephalometric tracings were used to produce the black silhouettes. The cephalometric analysis software previously described exported the images in gray scale at a resolution of $300 \mathrm{dpi}$ and saved them in JPG file format. All the tracings were rotated until the Frankfort horizontal plane was parallel to the ground and then converted into solid black-colored silhouettes by a single computer technician who understood the purpose of the study, using the Corel-Draw software (Corel, Ottawa, Ontario, Canada) according to a technique described in previous studies ${ }^{10,11}$.

All the silhouettes extended from a point right above the glabella to another right below the crossing of the chin and neck lines. The silhouettes were transferred to the text edition software (Windows Word, Microsoft, Redmond, Wash) and an album containing all the silhouettes of the 24 patients was created for the evaluation. In this album, two profiles of each patient (pre- and post-treatment) were displayed on the same page, but in random order, meaning the initial profile might be to the right or to the left of the page. Right below, fields were positioned for the patients to provide their responses to the perception research (Figure 1).
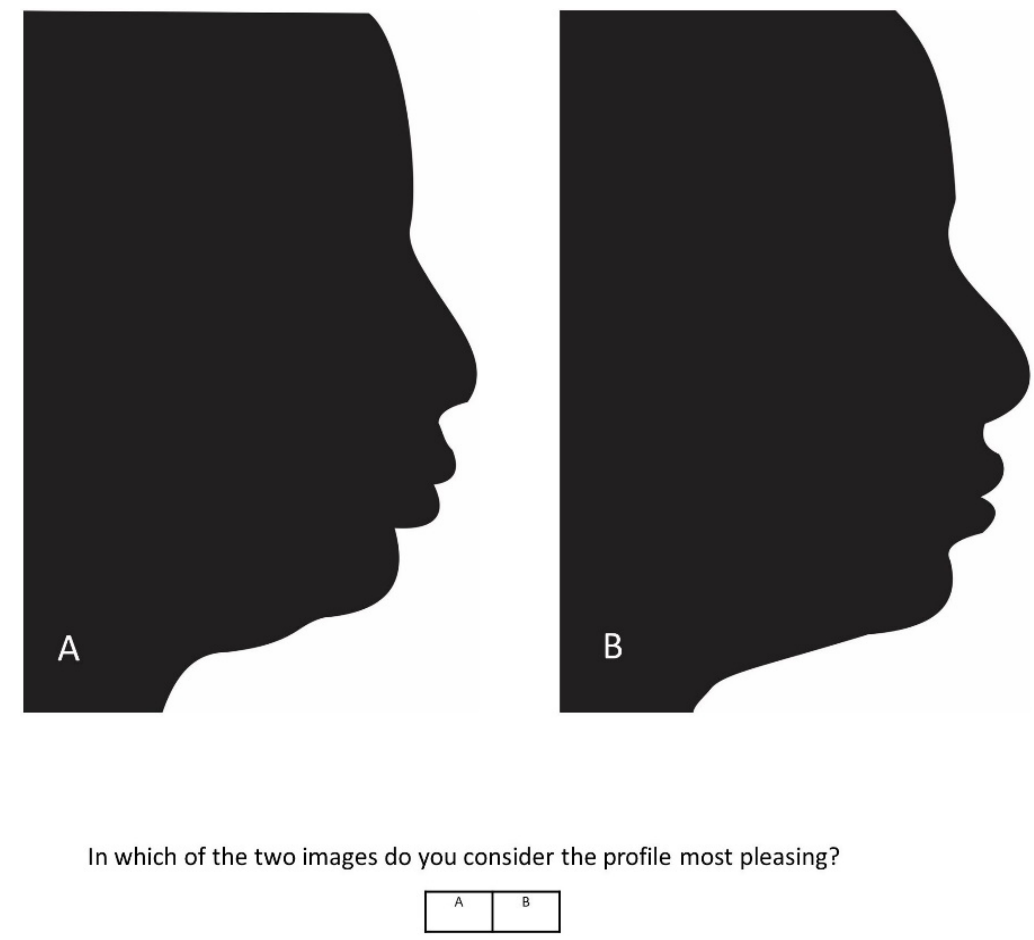

What is the quantity of change you are able to note between the two images?

Equal

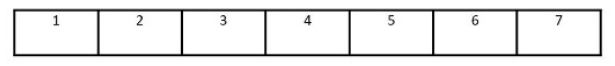

Very different 
Figure 1. Black silhouettes and their random disposition in the response booklets. Immediately below, the questions corresponding to the choice between the silhouettes and to the evaluation of change, using the 7-point Likert scale.

The same random process was used to determine the sequence of patients on the pages of the album. Only the author's album had the silhouettes with a corresponding code for phase identification (pre- and post-treatment) to facilitate the evaluation of results. The profiles were presented and judged based on the methodologies previously described in the literature ${ }^{10,11}$. The first author of this study was the interviewer and the patients treated were the evaluators. Each album was identified with the complete name of each patient, presenting instructions to answer the questions. On the first pages, five silhouettes were presented so the evaluators would get familiar with the esthetic variation in the sample. These silhouettes were presented in decreasing time intervals of $30,20,15,12$, and 10 seconds.

The presentation continued with 10 seconds available for choosing the response of each pair of silhouettes evaluated. The evaluators were instructed to indicate their profile preferences (A or B) and amount of change they were able to perceive between both profiles, according to a Likert scale from 1 (no difference) to 7 (significantly different).

According to the results of the perception analysis, two groups of patients were formed. Group 1 included those who judged the pre-treatment profile as more esthetically pleasing and Group 2 consisted of patients who classified the post-treatment profile as the most pleasing. Based on these groups, the variations in cephalometric measurements were compared with patient perceptions.

Changes between pre- and post-treatment values for each cephalometric variable were verified by Student's t-test and t-test for heterogeneous variances. Exploratory analyses were performed on the data and mixed-models methodology for time-repeated measures by the PROC MIXED and PROC GENMOD procedures, comparing groups, times, and interactions between them for each cephalometric measurement. In all cases, 5\% significance level was considered and the software used were SAS (SAS Institute Inc., Cary, NC, USA, Release 9.2, 2010) and R Core Team (R: a Language and Environment for Statistical Computing) (R Foundation for Statistical Computing, Vienna, Austria. 2016).

\section{RESULT}

The evaluation of esthetic preference before and after orthodontic treatment using the mandibular advancement device revealed that $75 \%$ of the evaluators preferred the post-treatment silhouettes. The mean value of the Likert scores showed no significant difference ( $p>0.05)$ between Group 1 (preference for pre-treatment) and Group 2 (preference for post-treatment). The perception of changes was close to position 4 in the scale for both groups, regardless of the choice for either pre- or post-treatment.

Tables 1 to 3 present the comparison between cephalometric measurements and the opinion of volunteers. Group 1 included six patients and Group 2 had 18 patients. After therapy, a significant increase was found in the values of the following measurements: Mandibular incisor (/1-NB and /1.NB), IMPA, Lii-(A-Pog), and Ocl.SN. The A-N.B variables, Upper Lip S line, Upper Lip E line, Holdaway's $H$ line, Wits, and the ratio between "Pog-NB" and "/1-NB" showed significant reduction $(\mathrm{p}<0.05)$. However, the cephalometric changes presented the same behavior 
in both groups. There were no significant differences in the values of the cephalometric variables between the two groups ( $\mathrm{p}>0.05)$.

Table 1. Mean (standard deviation) of skeletal variables (according to time and group) relative to the evaluators' perceptions

\begin{tabular}{|c|c|c|c|}
\hline \multirow{2}{*}{ Group } & \multicolumn{2}{|c|}{ Time } & \multirow{2}{*}{$\begin{array}{c}\text { Differences between groups* } \\
\text { (T2 }-\mathrm{T} 1)\end{array}$} \\
\hline & Pre & Post & \\
\hline & \multicolumn{2}{|c|}{ S-N.A } & \\
\hline Did not improve $(n=6)$ & 82.73 (5.11) Аa & $82.37(4.98) \mathrm{Aa}$ & $-0.36(0.58)$ \\
\hline \multirow[t]{2}{*}{ Improved $(\mathrm{n}=18)$} & $82.50(2.83) \mathrm{Aa}$ & 81.85 (2.99) Aa & $-0.65(1.92)$ \\
\hline & \multicolumn{2}{|c|}{ S-N.B } & \\
\hline Did not improve $(n=6)$ & 77.55 (4.35) Aa & $78.17(4.50) \mathrm{Aa}$ & $0.61(0.74)$ \\
\hline \multirow[t]{2}{*}{ Improved (n=18) } & $76.12(2.14) \mathrm{Aa}$ & $77.19(2.25) \mathrm{Aa}$ & $1.07(1.92)$ \\
\hline & \multicolumn{2}{|c|}{ A-N.B } & \\
\hline Did not improve $(n=6)$ & $4.91(1.36) \mathrm{Aa}$ & $4.20(1.91) \mathrm{Ba}$ & $-0.71(0.60)$ \\
\hline \multirow[t]{2}{*}{ Improved (n=18) } & $6.39(2.04) \mathrm{Aa}$ & $4.66(1.47) \mathrm{Ba}$ & $-1.73(1.80)$ \\
\hline & \multicolumn{2}{|c|}{ Ocl.SN } & \\
\hline Did not improve $(n=6)$ & $12.24(5.68) \mathrm{Ba}$ & $16.67(4.54) \mathrm{Aa}$ & $4.43(4.83)$ \\
\hline \multirow[t]{2}{*}{ Improved (n=18) } & 12.90 (4.47) Ba & $18.22(4.36) \mathrm{Aa}$ & $5.32(3.01)$ \\
\hline & \multicolumn{2}{|c|}{ Go-Gn.SN } & \\
\hline Did not improve $(n=6)$ & 32.89 (7.04) Аa & 33.31 (6.78) Aa & $0.41(1.30)$ \\
\hline \multirow[t]{2}{*}{ Improved (n=18) } & $33.70(3.71) \mathrm{Aa}$ & $33.80(3.63) \mathrm{Aa}$ & $0.10(1.92)$ \\
\hline & \multicolumn{2}{|c|}{ SN.Gn } & \\
\hline Did not improve $(n=6)$ & $68.00(4.43) \mathrm{Aa}$ & $68.89(4.45) \mathrm{Aa}$ & $0.90(1.32)$ \\
\hline \multirow[t]{2}{*}{ Improved (n=18) } & $69.31(2.87) \mathrm{Aa}$ & $69.58(2.62) \mathrm{Aa}$ & $0.27(1.65)$ \\
\hline & \multicolumn{2}{|c|}{ Wits } & \\
\hline Did not improve $(n=6)$ & $2.72(1.58) \mathrm{Aa}$ & $-2.09(3.90) \mathrm{Ba}$ & $-4.81(4.17)$ \\
\hline Improved (n=18) & $3.47(3.42) \mathrm{Aa}$ & $-1.31(3.28) \mathrm{Ba}$ & $-4.79(3.14)$ \\
\hline
\end{tabular}

Means followed by different letters (capitals in the horizontal and lower case in the vertical comparing the groups within each measurement) differed significantly among them $(\mathrm{p}<0.05) .{ }^{*}$ There was no significant difference between the groups with regard to change in the measurements $(\mathrm{p}>0.05)$.

Table 2. Mean (standard deviation) of dental variables (according to time and group) relative to the evaluators' perceptions

\begin{tabular}{|c|c|c|c|}
\hline \multirow{2}{*}{ Group } & \multicolumn{2}{|c|}{ Time } & \multirow{2}{*}{$\begin{array}{c}\text { Differences between groups* } \\
\text { (T2 - T1) } \\
\end{array}$} \\
\hline & Pre & Post & \\
\hline \multicolumn{4}{|c|}{ Upper incisor-NA } \\
\hline Did not improve $(n=6)$ & 5.50 (3.39) Aa & $5.29(3.57) \mathrm{Aa}$ & $-0.21(1.00)$ \\
\hline Improved $(\mathrm{n}=18)$ & $4.54(1.97) \mathrm{Aa}$ & $4.61(1.92) \mathrm{Aa}$ & $0.07(1.86)$ \\
\hline \multicolumn{4}{|c|}{ Upper incisor.NA } \\
\hline Did not improve $(n=6)$ & $24.89(14.50) \mathrm{Aa}$ & $21.46(13.07) \mathrm{Aa}$ & $-3.44(3.35)$ \\
\hline Improved $(\mathrm{n}=18)$ & $22.76(8.46) \mathrm{Aa}$ & $21.40(5.50) \mathrm{Aa}$ & $-1.36(7.56)$ \\
\hline \multicolumn{4}{|c|}{ Lower incisor-NB } \\
\hline Did not improve $(n=6)$ & $6.73(1.51) \mathrm{Ba}$ & $7.99(1.05) \mathrm{Aa}$ & $1.26(0.74)$ \\
\hline Improved $(n=18)$ & $5.93(1.74) \mathrm{Ba}$ & $7.55(1.79) \mathrm{Aa}$ & $1.62(0.84)$ \\
\hline \multicolumn{4}{|c|}{ Lower incisor.NB } \\
\hline Did not improve $(n=6)$ & 30.48 (4.12) Ba & $34.51(5.04) \mathrm{Aa}$ & $4.03(4.41)$ \\
\hline Improved $(\mathrm{n}=18)$ & $28.98(6.64) \mathrm{Ba}$ & $33.54(6.13) \mathrm{Aa}$ & $4.56(4.65)$ \\
\hline \multicolumn{4}{|c|}{ IMPA } \\
\hline Did not improve $(n=6)$ & $100.03(7.95) \mathrm{Ba}$ & $103.03(9.17) \mathrm{Aa}$ & $3.00(4.26)$ \\
\hline Improved $(n=18)$ & $99.16(6.49) \mathrm{Ba}$ & $102.55(6.49) \mathrm{Aa}$ & $3.38(4.40)$ \\
\hline \multicolumn{4}{|c|}{ Lower incisor-A.Pog } \\
\hline Did not improve $(n=6)$ & $2.80(1.81) \mathrm{Ba}$ & $4.85(1.90) \mathrm{Aa}$ & $2.05(1.18)$ \\
\hline Improved $(\mathrm{n}=18)$ & $1.06(2.47) \mathrm{Ba}$ & $3.86(2.01) \mathrm{Aa}$ & $2.80(2.03)$ \\
\hline \multicolumn{4}{|c|}{ Pog-NB } \\
\hline Did not improve $(n=6)$ & 1.38 (1.24) Aa & $0.59(1.52) \mathrm{Aa}$ & $-0.78(1.13)$ \\
\hline Improved $(\mathrm{n}=18)$ & $1.57(1.86) \mathrm{Aa}$ & $1.36(1.54) \mathrm{Aa}$ & $-0.21(0.67)$ \\
\hline
\end{tabular}


Means followed by different letters (capitals in the horizontal and lower case in the vertical comparing the groups within each measurement) differed significantly among them $(\mathrm{p}<0.05)$. ${ }^{*}$ There was no significant difference between the groups with regard to change in the measurements $(\mathrm{p}>0.05)$.

Table 3. Mean (standard deviation) of tegumentary variables (according to time and group) relative to the evaluators' perceptions

\begin{tabular}{|c|c|c|c|}
\hline \multirow{2}{*}{ Group } & \multicolumn{2}{|c|}{ Time } & \multirow{2}{*}{$\begin{array}{c}\text { \$Differences between groups } \\
\text { (T2 - T1) }\end{array}$} \\
\hline & Pre & Post & \\
\hline \multicolumn{4}{|c|}{ “Proportion Pog-NB and /1-NB" } \\
\hline Did not improve $(n=6)$ & $0.22(0.21) \mathrm{Aa}$ & $0.08(0.17) \mathrm{Ba}$ & $-0.14(0.17)$ \\
\hline Improved (n=18) & $0.38(0.55) \mathrm{Aa}$ & $0.24(0.32) \mathrm{Ba}$ & $-0.14(0.26)$ \\
\hline \multicolumn{4}{|c|}{ Upper lip-Line S } \\
\hline Did not improve $(n=6)$ & $-0.22(1.40) \mathrm{Aa}$ & $-1.60(1.74) \mathrm{Ba}$ & $-1.38(1.02)$ \\
\hline Improved (n=18) & $0.15(2.28) \mathrm{Aa}$ & $-1.25(1.83) \mathrm{Ba}$ & $-1.40(1.93)$ \\
\hline \multicolumn{4}{|c|}{ Lower lip-Line S } \\
\hline Did not improve $(n=6)$ & $0.53(2.75) \mathrm{Aa}$ & 0.23 (2.68) Aa & $-0.30(0.87)$ \\
\hline Improved $(n=18)$ & $0.98(2.61) \mathrm{Aa}$ & $0.96(2.39) \mathrm{Aa}$ & $-0.01(2.02)$ \\
\hline \multicolumn{4}{|c|}{ Nasolabial Angle } \\
\hline Did not improve $(n=6)$ & 117.03 (12.66) Aa & 118.77 (10.82) Аа & $1.74(4.23)$ \\
\hline Improved $(n=18)$ & $115.66(10.03) \mathrm{Aa}$ & $112.38(11.11) \mathrm{Aa}$ & $-3.28(7.15)$ \\
\hline \multicolumn{4}{|c|}{ Lower lip-Line E } \\
\hline Did not improve $(n=6)$ & $-0.39(2.99) \mathrm{Aa}$ & $-0.57(2.78) \mathrm{Aa}$ & $-0.18(1.03)$ \\
\hline Improved (n=18) & 0.07 (2.73) Aa & $-0.25(2.37) \mathrm{Aa}$ & $-0.32(2.07)$ \\
\hline \multicolumn{4}{|c|}{ Upper lip- Line E } \\
\hline Did not improve $(n=6)$ & $-1.71(1.74) \mathrm{Aa}$ & $-2.89(1.99) \mathrm{Ba}$ & $-1.18(1.10)$ \\
\hline Improved $(n=18)$ & $-1.35(2.51) \mathrm{Aa}$ & $-3.17(1.83) \mathrm{Ba}$ & $-1.82(2.10)$ \\
\hline \multicolumn{4}{|c|}{ Line $\mathrm{H}$ of Holdaway } \\
\hline Did not improve $(n=6)$ & $13.54(4.64) \mathrm{Aa}$ & $12.47(4.92) \mathrm{Ba}$ & $-1.07(2.51)$ \\
\hline Improved (n=18) & $14.78(5.11) \mathrm{Aa}$ & $11.97(4.04) \mathrm{Ba}$ & $-2.82(3.54)$ \\
\hline
\end{tabular}

Means followed by different letters (capitals in the horizontal and lower case in the vertical comparing the groups within each measurement) differed significantly among them $(\mathrm{p}<0.05)$. \$ There was no significant difference between the groups with regard to change in the measurements $(\mathrm{p}>0.05)$.

\section{DISCUSSION}

The esthetic perception of patients is valued in orthodontics $6-8,10,15,16$. Thus, there should exist a concern to provide facial balance and harmony and not just adequate occlusion ${ }^{7}$. For this purpose, cephalometry is still used to guide the goals of orthodontic therapy, but the use of isolated cephalometric numbers as a basis is not indicated, considering they do not consider the esthetic satisfaction of patients at the end of treatment ${ }^{7,8,11}$.

The cephalometric results of the present study were distant from the normative values, with protrusion and significant vestibularization in all the variables related to mandibular incisors. Nevertheless, the findings showed that $75 \%$ of evaluators chose post-treatment as the best option in the visual perception evaluation, which agrees with other studies on esthetic perception ${ }^{6,7}$. Differences deviating from the cephalometric values considered optimal for satisfactory facial esthetics did not affect the choice.

Therefore, studies related to the effects of the device used in the methodology of the present study, showing the same effects on teeth ${ }^{5,17-19}$, should be interpreted with caution, as there is a tendency to assume these changes lead to worse facial esthetic perception, which does not seem to fit the reality.

Perhaps the explanation may be obtained by observing the behavior of other variables when comparing pre- and post-treatment. For instance, the unchanged position of the lower lips in relation to the $\mathrm{E}$ and $\mathrm{S}$ esthetic lines, along with a significant change of the upper lips in relation to the same esthetic lines, although the positions of upper incisors did not present significant changes. This apparently controversial situation detected in other studies ${ }^{17}$ is a potential soft tissue adaptation due to the anterior positioning of the chin and the nasal growth that repositioned the reference points in which the esthetic lines are traced ${ }^{11,17}$. 
After confirming the preference for post-treatment, the perception regarding the amount of profile change was evaluated with the 7-point Likert scale. This method, which is used in several studies, was chosen because it is simple and easy to understand and it is applied by the evaluators ${ }^{10,11}$. The Likert scale analysis resulted in a mean value of approximately 4 and the silhouettes were similarly perceived, regardless of whether the profile chosen as the most esthetic represented the pre- or post-treatment profile. The result expected would be the perception of little difference between the silhouettes of the group that preferred the pre-treatment images, because it represented deficiency in correcting the position of the lower anterior region of the face, which is the action site of the therapy. The craniofacial growth present in all the patients treated in this study may possibly have produced facial changes in the region of the chin, nose, and forehead. These may have been sufficient to cause perceptible facial characteristics that allowed the evaluators to perceive differences between the pre- and post-treatment images, with scale values close to those of the group favoring post-treatment profiles ${ }^{20,21}$. This may be a limitation of the study, because the growth factor caused changes in facial shape that could not be controlled. However, ethically, patients with malocclusions had to be treated within the time indicated for therapy, which includes the growth spurt period 22 .

Another question considering the age of patients in the sample would be the ability to evaluate the silhouettes. Esthetic perception was evaluated after the end of treatment, at the chronological age of over 13 years, based on the average of the post-treatment radiographic measurements. Thus, the patients were fit to evaluate the results. Studies have found that children tend to increase agreement with adult esthetic preferences as they develop through the years ${ }^{23-25}$ and, after the age of 12 years, the differences with adults are small 25 .

The attempt to associate the variations of normative cephalometric measurements with patient perception concluded that patients showed no distinct behaviors when compared with each other, regardless of whether the silhouette was considered better or worse at the end of treatment. Therefore, no association was found between normative values and visual perception. The evaluators potentially observed characteristics that were not affected directly by the cephalometric variables studied, such as the position and size of the nasal tip and dorsum and their balance with the position of the chin and forehead. Studies seeking the association between cephalometric values and perception also showed similar results 8,9 .

A fact to be considered is that, because the positive post-treatment approval showed a high percentage (75\%), Group 1 ended up with a smaller number of patients. To reach a larger number of patients in Group 1, following the proportion of the results obtained, would require a large number of patients in Group 2, which would make the study unfeasible because of the difficulty in obtaining such sample. By statistical circumstances, increasing the number of participants might increase the chance of revealing some variable with significant variation. However, even with the present sample, it was possible to verify that cephalometric measurements tend to behave similarly in all patients, following the behavior detected in studies previously published in the literature that focused on cephalometric changes resulting from treatment with mandibular protractors. Thus, variable behaviors were expected to be similar, without differences between the two groups studied $5,17-19$.

Although there was no association defined between cephalometry and esthetic perception, results that could be even more distant from the predefined cephalometric standards were accepted and might explain the preference for the post-treatment images after mandibular advancement ${ }^{6,7}$.

Cephalometry is still a good starting point and it should not be ruled out, especially for beginners in orthodontics. However, it is recommended to combine it with the patient's individual opinion, perhaps through the self-assessment of a profile picture or using self-perception indexes when seeking more assertiveness regarding esthetic needs and patient satisfaction at the end of therapy. 
Further studies aiming to determine which factors patients consider when making esthetic choices and perhaps seeking new diagnosis methods that may be associated with their preferences may bring new answers and help determining the best bases for diagnosis, prognosis, and evaluation of orthodontic treatment results.

\section{CONCLUSION}

There was no association between normative cephalometric results and the perception of esthetic improvement by patients treated for mandibular retrognathia.

\section{ACKNOWLEDGEMENTS}

We would like to thank all the volunteers who participated in the study, as well as Rafael Bovi Ambrosano for his valuable help and advice on the statistical analysis.

\section{REFERENCES}

1. Bittencourt JM, Martins LP, Bendo CB, Vale MP, Paiva SM. Negative effect of malocclusion on the emotional and social well-being of Brazilian adolescents: a population-based study. Eur J Orthod. 2017 Nov;39(6):628-33. http://dx.doi.org/10.1093/ejo/cjx020. PMid:28371848.

2. Badran SA. The effect of malocclusion and self-perceived aesthetics on the self-esteem of a sample of Jordanian adolescents. Eur J Orthod. 2010 Dec;32(6):638-44. http://dx.doi.org/10.1093/ejo/cjq014. PMid:20403957.

3. Torsello F, Graci M, Grande NM, Deli R. Relationships between facial features in the perception of profile attractiveness. Prog Orthod. 2010;11(2):92-7. http://dx.doi.org/10.1016/j.pio.2010.04.002. PMid:20974445.

4. Holdaway RA. A soft-tissue cephalometric analysis and its use in orthodontic treatment planning. Part I. Am J Orthod. 1983 Jul;84(1):1-28. http://dx.doi.org/10.1016/0002-9416(83)90144-6. PMid:6575614.

5. Yang X, Zhu Y, Long H, Zhou Y, Jian F, Ye N, et al. The effectiveness of the Herbst appliance for patients with Class II malocclusion: a meta-analysis. Eur J Orthod. 2016 Jun;38(3):324-33. http://dx.doi.org/10.1093/ejo/cjv057. PMid:26306822.

6. Rego MV, Martinez EF, Coelho RM, Leal LM, Thiesen G. Perception of changes in soft-tissue profile after Herbst appliance treatment of Class II Division 1 malocclusion. Am J Orthod Dentofacial Orthop. 2017 Mar;151(3):559-64. http://dx.doi.org/10.1016/j.ajodo.2016.08.028. PMid:28257740.

7. Paula ECM, Conti ACCF, Siqueira DF, Valarelli DP, Almeida-Pedrin RR. Esthetic perceptions of facial silhouettes after treatment with a mandibular protraction appliance. Am J Orthod Dentofacial Orthop. 2017 Feb;151(2):311-6. http://dx.doi.org/10.1016/j.ajodo.2016.06.038. PMid:28153160.

8. Oh HS, Korn EL, Zhang X, Liu Y, Xu T, Boyd R, et al. Correlations between cephalometric and photographic measurements of facial attractiveness in Chinese and US patients after orthodontic treatment. Am J Orthod Dentofacial Orthop. 2009 Dec;136(6):762.e1-14, discussion 762-3. http://dx.doi.org/10.1016/j.ajodo.2009.04.020. PMid:19962590.

9. Salmória I, Furtado A, Rosário HD, Furtado GC, Paranhos LR. Análise facial de arnett e Bergman comparada a percepção estética de leigos e cirurgiões-dentistas (clínicos gerais e ortodontistas). Biosci J. 2014 Jan-Feb;30(1):297-303.

10. Mann KR, Marshall SD, Qian F, Southard KA, Southard TE. Effect of maxillary anteroposterior position on profile esthetics in headgear-treated patients. Am J Orthod Dentofacial Orthop. 2011 Feb;139(2):228-34. http://dx.doi.org/10.1016/j.ajodo.2010.04.031. PMid:21300252.

11. Mergen JL, Southard KA, Dawson DV, Fogle LL, Casko JS, Southard TE. Treatment outcomes of growing Class II Division 1 patients with varying degrees of anteroposterior and vertical dysplasias. Part 2. 
Profile silhouette evaluation. Am J Orthod Dentofacial Orthop. 2004 Apr;125(4):457-62. http://dx.doi.org/10.1016/j.ajodo.2003.06.004. PMid:15067262.

12. Marchiori GE, Sodre LO, da Cunha TC, Torres FC, Rosario HD, Paranhos LR. Pleasantness of facial profile and its correlation with soft tissue cephalometric parameters: perception of orthodontists and lay people. Eur J Dent. 2015 Jul-Sep;9(3):352-5. http://dx.doi.org/10.4103/1305-7456.163323. PMid:26430362.

13. Moro A, Fuziy A, Freitas MR, Henriques JFC, Janson GRP. Descrição passo-a-passo do aparelho de Herbst com coroas de aço superiores e "Splint" removível inferior. Rev Dental Press Ortodon Ortop Maxilar. 2001 Maio-Jun;6(3):55-62.

14. Perinetti G, Contardo L, Castaldo A, McNamara JA Jr, Franchi L. Diagnostic reliability of the cervical vertebral maturation method and standing height in the identification of the mandibular growth spurt. Angle Orthod. 2016 Jul;86(4):599-609. http://dx.doi.org/10.2319/072415-499.1. PMid:26600421.

15. Nomura M, Motegi E, Hatch JP, Gakunga PT, Ng'ang'a PM, Rugh JD, et al. Esthetic preferences of European American, Hispanic American, Japanese, and African judges for softtissue profiles. Am J Orthod Dentofacial Orthop. 2009 Apr;135(4 Suppl):S87-95. http://dx.doi.org/10.1016/j.ajodo.2008.02.019. PMid:19362272.

16. Santos PR, Meneghim MC, Ambrosano GM, Filho MV, Vedovello SA. Influence of quality of life, selfperception, and self-esteem on orthodontic treatment need. Am J Orthod Dentofacial Orthop. 2017 Jan;151(1):143-7. http://dx.doi.org/10.1016/j.ajodo.2016.06.028. PMid:28024768.

17. Flores-Mir C, Major MP, Major PW. Soft tissue changes with fixed functional appliances in Class II division 1. Angle Orthod. 2006 Jul;76(4):712-20. PMid:16808582.

18. Zymperdikas VF, Koretsi V, Papageorgiou SN, Papadopoulos MA. Treatment effects of fixed functional appliances in patients with Class II malocclusion: a systematic review and meta-analysis. Eur J Orthod. 2016 Apr;38(2):113-26. http://dx.doi.org/10.1093/ejo/cjv034. PMid:25995359.

19. Kinzinger GSM, Lisson JA, Frye L, Gross U, Hourfar J. A retrospective cephalometric investigation of two fixed functional orthodontic appliances in class II treatment: functional mandibular Advancer vs. Herbst appliance. Clin Oral Investig. 2018 Jan;22(1):293-304. http://dx.doi.org/10.1007/s00784-0172111-5. PMid:28365810.

20. Rudee DA. Proportional profile changes concurrent with orthodontic therapy. Am J Orthod. 1964 Jun;50(6):421-34. http://dx.doi.org/10.1016/0002-9416(64)90205-2.

21. Enlow D, Hans M. Essentials of facial growth. 2nd ed. Ann Arbor: Needham Press; 2008. 504 p.

22. Ruf S, Pancherz H. When is the ideal period for Herbst therapy - early or late? Semin Orthod. 2003 Mar;9(1):47-56. http://dx.doi.org/10.1053/sodo.2003.34024.

23. Kissler J, Bäuml KH. Effects of the beholder's age on the perception of facial attractiveness. Acta Psychol (Amst). 2000 May;104(2):145-66. http://dx.doi.org/10.1016/S0001-6918(00)00018-4. PMid:10900703.

24. Vingilis-Jaremko L, Maurer D. The influence of averageness on children's judgments of facial attractiveness. J Exp Child Psychol. 2013 Aug;115(4):624-39. http://dx.doi.org/10.1016/j.jecp.2013.03.014. PMid:23708730.

25. Cooper PA, Geldart SS, Mondloch CJ, Maurer D. Developmental changes in perceptions of attractiveness: a role of experience? Dev Sci. 2006 Sep;9(5):530-43. http://dx.doi.org/10.1111/j.14677687.2006.00520.x. PMid:16911455.

\section{CONFLICTS OF INTERESTS}

The authors declare no conflicts of interest. 


\section{*CORRESPONDING AUTHOR}

Viviane Veroni Degan, UNIARARAS - Centro Universitário Hermínio Ometto, Departamento de Ortodontia, Avenida Doutor Maximiliano Baruto, 500, 13607-339 Araras - SP, Brasil, e-mail: vivianedegan@fhoedu.br

Received: June 27, 2019

Accepted: August 5, 2019 